International Journal of Public Health Excellence (IJPHE)

Vol. 1, No. 1, January 2022, pp. 32 34

Journal homepage: https://ejournal.ipinternasional.com/index.php/ijphe/

ISSN: 2809-9826, DOI: https://doi.org/10.55299/ijphe.v1i1.9

\title{
Factors in the Selection of Uterine Contraceptives in Women of Childbearing
} Age

\author{
Ennysah Hasibuan ${ }^{1}$, Meilani Harahap ${ }^{2}$, Nikmatul Khoiriyah Pulungan ${ }^{3}$ \\ ${ }^{1,2,3}$ Diploma 3 Study Program, Matorkis Academy of Midwifery, Padangsidimpuan, Indonesia
}

\begin{tabular}{|c|c|}
\hline Article Info & ABSTRACT \\
\hline Article history: & Intrauterine contraceptives are devices or objects that are inserted into the \\
\hline Received November 23, 2021 & $\begin{array}{l}\text { uterus which are very effective, reversible and long-term, and can be used by } \\
\text { all women of reproductive age. The study design was an observational }\end{array}$ \\
\hline Revised December 03, 2021 & analytic survey with a case-control design that was conducted by comparing \\
\hline Accepted December 29, 2021 & $\begin{array}{l}\text { those who did not use an intrauterine device (IUD) as a case with those who } \\
\text { used an intrauterine device (IUD) as a control. The sampling method in this }\end{array}$ \\
\hline Corresponding Author: & $\begin{array}{l}\text { study is proportional. The population in this study were women with pus } \\
\text { with a total sample of } 96 \text { people. The results of the bivariate analysis of }\end{array}$ \\
\hline Ennysah Hasibuan & knowledge $\mathrm{p}=0.000$ value obtained OR 9.348 (95\% CI: 3.157-27.678), \\
\hline Diploma 3 Study Program, & 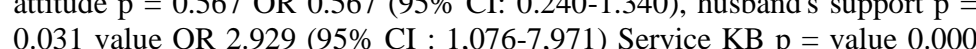 \\
\hline Matorkis Academy of & OR 5,909 (95\% CI: 2,290-15,248). The most influential multivariate results \\
\hline $\begin{array}{l}\text { Midwifery, Padangsidimpuan, } \\
\text { Indonesia }\end{array}$ & from knowledge $\mathrm{p}=$ value 0.001 OR 6.472 . The conclusion of the research \\
\hline Email:nysah27@gmail.com & $\begin{array}{l}\text { family planning services. And the most influential factor in choosing an IUD } \\
\text { is the husband's attitude and support. }\end{array}$ \\
\hline
\end{tabular}

Keywords:

Election, Contraception, Womb, Woman, Family Planning

This article is licensed under a Creative Commons AttributionShareAlike 4.0 International License.

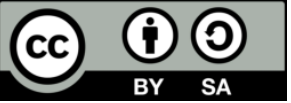

\section{INTRODUCTION}

The Family Planning Program is a means to achieve a reduction in the birth rate. According to [2], couples of childbearing age (EFA) are married couples whose wives are between 15 and 49 years old or married couples whose wives are less than 15 years old and have menstruation or wives who are more than 50 years old. old, but still menstruating (the next few months). Based on the results of the 2008 National Socio-Economic Survey, the percentage of women aged 10 years and over who have ever been married with a number of live-born children is $0-2$ people $(49.72 \%)$ and $3-5$ people $(35.83 \%)$ ) for urban areas and countryside. The fertile period of a woman has an important role for the occurrence of pregnancy so that the chances of a woman are usually between 15-49 years. Therefore, to regulate the number of births or birth spacing, these women or couples are prioritized to use family planning tools or methods [16].

Until now, the use of long-term contraceptives in Indonesia is still a concern. The BKKBN continues to encourage people to switch to long-term contraception, but to no avail. The BKKBN continued to encourage the use of MKJP (long-term contraceptive method) but in 2012 only 17 percent was achieved, and in 2017 it fell to 14 percent. But more sadly, the use of injections is even higher. Most are given by private midwives, and injections are given once a month, according to the graph, the use of injectable contraceptives has continued to increase in the last three years. Therefore, to increase MKJP users, BKKBN has created a midwifery program for one district that can provide tubectomy, and one general practitioner who can provide vasectomy, which will be launched next year. The BKKBN is also working to reduce injectable contraceptives and encourage MKJP with IUDs, implants in collaboration with the Indonesian Midwives Association (IBI) and providers serving family planning services to improve MKJP. 48,000 midwives and 11,000 general practitioners were trained in IUD insertion and insertion methods. The BKKBN is also working to reduce injectable contraceptives and encourage MKJP with IUDs, implants and sterilization in collaboration with the Indonesian Midwives Association (IBI) and providers serving Int Jou of PHE 
family planning services to improve MKJP. 48,000 midwives and 11,000 general practitioners were trained in IUD insertion and insertion methods. The achievement of family planning acceptors or CPR (Contraceptive Participant Rate) is 57.9 percent with tools and 65 percent without tools.

The target for the next five years is 63.5 percent with tools. Meanwhile, the Total Fertility Rate (TFR) is 2.3 percent. In theory, if the CPR has reached 60 percent then the TFR could be 2.1 percent. If these conditions can be created then population growth can be stable. Now the number of births per year is 4.5 million. While the resources for human development have not been able to keep up. This is a source of the problem of poverty that is difficult to reduce [2]

\section{METHOD}

Research method The type of research used is an observational analytic survey with a case control design which was conducted by comparing those who did not use contraceptives (IUD) as cases with those who used contraceptives (IUDs) as controls. The reason for using this design is because this research design is retrospective, respondents only feel able to do something if the sample is part of the population that is expected to represent or represent the population [6]. In this study the sample was divided into 2, namely case samples and control samples, namely: Case samples of mothers who did not use contraception in the womb at the Pijorkoling Public Health Center, Padangsidimpuan Southeast District in 2018. While the Control Sample Mothers who used intrauterine contraceptives at the Pijorkoling District Health Center Southeast Padangsidimpuan 2018.

\section{RESULTS AND DISCUSSION}

The results of the analysis showed that based on knowledge, there were 66 respondents (68.8\%). While those who have good knowledge are 30 people $(31.1 \%)$. The results of the bivariate analysis of knowledge about the choice of contraception in the womb obtained an Odds ratio value of 9.348 (95\% CI: 3.157-27.678), meaning that respondents with little knowledge had a 9.348 times less chance of getting pregnant. choose contraception. With $p=$ 0.000 , which means that there is a significant relationship between knowledge and the choice of intrauterine device. The results of the analysis show that based on the positive attitude of respondents, 64 people $(66.7 \%)$. While the negative there were 32 people $(33.3 \%)$.

The results of the bivariate analysis of attitudes towards the selection of contraceptives in the womb obtained an Odds ratio of 0.567 (95\% CI: 0.240-1.340), meaning that respondents who gave responses were 0.567 times more likely to choose contraceptives in the womb. With a value of $\mathrm{p}=0.198$, which means there is no significant relationship between attitudes and the choice of contraceptives in the womb. Attitude is a person's closed response to a certain stimulus or object, which already involves income and related emotional factors (happy, unhappy, agree, disagree). agree, good, not good, etc. Campbell (1950) defines it very simply, namely "An individual's attitude is a response consistency syndrome with respect to objects. So it is clear here that attitude is a pavement or a collection of symptoms in response to a stimulus or object, so that attitudes involve thoughts, feelings, concerns, etc. psychological symptoms

\section{CONCLUSION}

Based on the results of research on the determinants of the selection of contraceptives (IUD) in women of childbearing age at the Pijorkoling Health Center, Southeast Padangsidimpuan District in 2018, it can be concluded that there is a significant relationship with knowledge of choosing contraceptives in the womb at the Pijorkoling Health Center, Southeast Padangsidimpuan Regency in 2018, this can be seen from the many knowledgeable women of childbearing age who do not choose contraceptives in the womb. There is no relationship between attitudes towards the selection of contraceptives in the womb at the Pijorkoling Health Center, Southeast Padangsidimpuan Regency in 2018, this can be seen from the number of women of childbearing age who gave a positive response but did not choose contraception in the womb. There is a relationship between husband's support for the selection of contraceptives in the womb at the Pijorkoling Health Center, Southeast Padangsidimpuan Regency in 2018, this can be seen from the number of women of childbearing age who get husband's support to choose contraceptives in the womb. There is a relationship between family planning services and the selection of contraceptives in the womb at the Pijorkoling Health Center, Southeast Padangsidimpuan Regency in 2018, this can be seen from the number of good family planning services in choosing contraceptives in the womb. After the multivariate test was conducted, it was found that 3 determinant variables which were the final model statistically had a dominant influence, namely knowledge with an OR of 6,472 ( $p<0.01$ ), family planning services with an OR of $3,740(\mathrm{p}<0.012)$. The most dominant variable influencing the choice of intrauterine device at the Puskesmas was knowledge with an OR of $6.472(\mathrm{p}<0.01)$.

\section{ACKNOWLEDGEMENTS}

Author thanks Meilani Harahap and Nikmatul Khoiriyah Pulungan In most cases, sponsor and financial support. 


\section{REFERENCES}

[1] Anggraini, Family Planning Services. Rohima Press. Vol. 1, $2^{\text {nd }}$ ed, Yogyakarta, Indonesia, 2017.

[2] BKKBN, "Population and Development Profile in Indonesia". [2016] Jakarta, Indonesia.

[3] Cunningham, Obstetri Williams. Vol. 1, $1^{\text {st }}$ ed, EGC, Jakarta, Indonesia, 2014.

[4] Department of health, "Population Data Target of Health Development Program". [2016] Jakarta, Indonesia

[5] Handayani, Family Planning Services. Vol. 1, $1^{\text {st }}$ ed, Rihama-Rohima, Yogyakarta, Indonesia, 2017.

[6] Hartanto, H. Family Planning and Contraception. Vol. 3, $3^{\text {rd }}$ ed, Pustaka Sinar Harapan. Jakarta, Indonesia , 2008.

[7] Sundari M, "Analysis of the Knowledge Level of Family Planning Acceptors About Contraceptive Devices at the Sedayu I Health Center in 2014”, Vol. 1 No. 1, pp 71-75 Doi:10.21927/jnki.2014.2(2).71-75

[8] Indonesian Ministry of Health. "Indonesian Health". [2015]. Jakarta, Indonesia

[9] Kusumaningrum, R. Factors Affecting the Selection of Types of Contraception Used by Couples of Childbearing Age. Vol. 1, $1^{\text {st }}$ ed, UNDIP. Semarang, Indonesia. 2009.

[10] Liando, Factors Associated with the Use of an Intrauterine Contraceptive Device. Vol. 1, $2^{\text {nd }}$ ed, Ilmiah Bidan. Semarang, Indonesia, 2013

[11] Marni, Family Planning Service. Vol. 1, $1^{\text {st }}$ ed, Pustaka Pelajar, Yogyakarta, Indonesia, 2016.

[12] Musdalifah, Factors Associated with Couples' Choice of Contraceptive Devices, Vol. 1, $1^{\text {st }}$ ed, Kesehatan Masyarakat, Pirang, Indonesia, 2016

[13] Notoatmodjo, Health Behavioral Science. Vol. 3, $3^{\text {rd }}$ ed, Rineka Cipta, Jakarta, Indonesia, 2016.

[14] Notoatmodjo, Health Research Methods. Vol. 2, $2^{\text {nd }}$ ed, Rineka Cipta, Jakarta, Indonesia, 2012

[15] Notoadmodjo, Health Research Methods. Vol. 1, $1^{\text {st }}$ ed, Rineka Cipta, Jakarta, Indonesia, 2005

[16] Ministry of Health of the Republic of Indonesia, "The Situation of Family Planning in Indonesia", [2013] Jakarta, Indonesia.

[17] Mardiansyah, "Analysis of Factors Related to the Use of Contraceptive Devices in Couples in Tamalanrea Indah Village, Tamalanrea District, Makassar City” Research thesis, pp 21-22, 2012. Universitas Hasanuddin, Makassar, Indonesia.

[18] Sugiarti \& Siti, "Couples Factors Affecting the Choice of Contraceptive Types in Couples of Childbearing Age" Thesis, pp 26-27, 2012, FIK Tasikmalaya, Tasikmalaya, Indonesia.

[19] Junita, T.P, "Factors Affecting the Selection of the Type of Contraception Used in Couples of Childbearing Age", Scientific Writing, pp 54, 2009, FKM UNDIP, Semarang, Indonesia.

[20] laws of the republic Indonesia No. 52 of 2009, “concerning Population Development and Family Development”, [2009], Jakarta, Indonesia.

[21] Tsui, Brown AO, Li W, Qingfeng. Contraceptive Practice in Sub-Saharan Africa. Popul Dev Rev. 2017; 43, 166-91. https://doi.org/10.1111/padr.12051 PMID: 29081552

[22] Eshete A. Contraceptive Method Mix Utilization and its Associated Factors among Married Women in Gedeo Zone, Southern Nations, Nationalityand People Region-Ethiopia: A Community based Cross Sectional Study. Epidemiology. 2015, 5:4

[23] Mohammed A, Woldeyohannes D, Feleke A, Megabiaw B. Determinants of modern contraceptive utili- zation among married women of reproductive age group in North Shoa Zone, Amhara Region, Ethiopia. Reproductive Health. 2014; 11:13 https://doi.org/10.1186/17424755-11-13

[24] Earsido A, Gebeyehu A, Kisi T. Determinants of Long Acting and Permanent Contraceptive Methods Utilization among Married Women in Hossana Town, Southern Ethiopia: A Case - Control Study. J Preg Child Health. 2015; 2:3.

[25] Alemayehu M, Belachew T, Tilahun T. Factors associated with utilization of long acting and permanent contraceptive methods among married women of reproductive age in Mekelle town, Tigray region, north Ethiopia. BMC Pregnancy and Childbirth. 2012; 12:6 https://doi.org/10.1186/1471-2393-12-6 